музики / підгот. до вид., наук. ред., вступ. ст., комент. Л. П. Корній ; літ. ред. Г. П. Півторака. Київ : Муз. Україна, 2003. С. 29-46.

7. Корній Л. П. Джерелознавство історії української музичної культури. Київ : ІМФЕ ім. М. Т. Рильського, 2019. 312 с.

8. Любомирський Г. Л. Практичний підручник елементарної теорії музики 3 додатком «Музикальний слух, його виховання та удосконалення» для учнів музичних шкіл і самоосвіти. Вид. 4-те. Київ : К.М.П, 1930. 108 с.

9. Любомирский Г. Л. Руководство к практическому изучению гармонии, приспособленное к самообучению и изложенное в 32 уроках. Курс 1-2. Киев : Изд. Л. Идзиковского, 1909-1913. Друге вид.: Курс 1. Киев ; Варшава : Изд. Л. Идзиковского, 1914. 142 с. Курс 2. Киев : Изд. Л. Идзиковского, 1913, 146 с.

10. Ольховський А. В. Нарис історії української музики / під ред. Ігоря Глебова [Б. В. Асаф’єва]. Київ : Мистецтво, 1941. 354 с.

11. Ольховський А. В. Тематичний план курсу історії української музики. Радянська музика. 1938. № 5. С. 18-28.

DOI https://doi.org/10.30525/978-9934-26-117-6-9

\title{
ДУХОВНА ХОРОВА ТВОРЧІСТЬ МИРОСЛАВА СКОРИКА В КОНТЕКСТІ ПОСТРАДЯНСЬКОГО МУЗИЧНОГО ПРОСТОРУ
}

\author{
Гусарчук Т. В. \\ доктор мистецтввознавства, \\ доцент, професор кафедри історії української музики \\ та музичної фольклористики \\ Національна музична академія Украйни імені П. І. Чайковського \\ м. Київ, Україна
}

Однією з найяскравіших тенденцій розвитку музичного мистецтва наприкінці XX - у перші десятиліття XXI століття став розквіт жанрів духовної музики, пов'язаний 3 ментальними пошуками, потребою в духовному оперті, поверненням до джерел національної культури.

У незалежній Україні міленіум відкрив нову золоту добу хорової творчості, тісно пов'язаної з духовною проблематикою і відповідними жанрами. До Лесі Дичко, яка ще наприкінці 1980-х років започаткувала цей новий напрямок, долучилися видатні майстри різних поколінь - 
Мирослав Скорик, Євген Станкович, Валентин Сильвестров, Юрій Іщенко, Віктор Степурко, Олександр Яковчук, Анна Гаврилець, Вікторія Польова, Олександр Козаренко та багато інших. «Твори на богослужбові та молитовні тексти $є$ у доробку практично кожного українського композитора», - підкреслює Віктор Степурко [5, с. 17]. «Чому останнім часом ми, композитори, звернулися до релігійної музики? - говорить Мирослав Скорик. - По-перше, тому що іiі було заборонено. А по-друге,- тому, що релігійна музика прагне бути морально чистою, одухотвореною, вимагає чистоти почуттів, віри, переживання, співчуття, участі- усього того, чого не вистачає у сучасному світі» $[4$, с. 2$]$.

Композитори по-різному вирішують проблему вибору вербальної основи для своїх творів, у їхній творчості ми спостерігаємо різні стильові конфігурації та жанрові трансформації. Тож перед виконавцями та музикознавцями відкрилося широке поле для творчих $\mathrm{i}$ наукових інтерпретацій. Актуальним стає питання про те, якою має бути сучасна літургічна музика. Обговорюючи його, культурологи $\mathrm{i}$ музиканти, священнослужителі, представники різних конфесій, долучаються до загальносвітового процесу.

Більша частина створюваної в останні десятиліття хорової літератури на канонічні тексти використовується виключно в концертному виконанні через складність сучасної музичної стилістики, високі вимоги до виконавської техніки та недотримання тих чи інших критеріїв, що унеможливлює виконання творів безпосередньо у богослужбовій практиці. Утім, звісно, створюються і піснеспіви спеціально для церковного вжитку, а також з'являються поодинокі композиції, що отримують «статус» багатофункціональності - виконуються і при богослужінні, і в концертах (наприклад, популярний духовний концерт Ігоря Тилика «Покаянія отверзи мі двері, Життєдавче»).

Одним із найяскравіших явищ у царині української духовної музики зазначеного періоду є хорові твори Мирослава Скорика. Композитор уперше звернувся до канонічних текстів у середині 1990-х років, тож його духовні твори позначені найвищою творчою зрілістю. У них виразно проявився індивідуальний стиль митця і водночас - провідні тенденції часу.

Духовно-музична спадщина М. Скорика включає обробку коляди «Не плач, Рахиле» (1994р.), «Духовний концерт-реквієм» (1998р., нова редакція - 2003 р.), три псалми - «Чи Ти, мій милий Боже», «Не карай мене, о Господи», «Боже, спаси мене» (2003 р.) та «Літургію святого Іоанна Златоустого» (2005р.). 
Безумовно, у духовній творчості М. Скорика виявилася така загальна тенденція сучасної української духовної музики, як глибинна опора на традиції православного співу (композитор не раз підкреслював, що мав за взірець національну спадщину - партесний концерт, твори М. Березовського, Д. Бортнянського, А. Веделя). Водночас він прагнув до оновлення, осучаснення музичної мови, яка, при всій іiі складності, використанні широкого спектру класико-романтичних та сучасних ладо-гармонічних засобів, залишається тональною. I саме у площині тонального розвитку часто розгортається драматургія творів, наприклад, у «Духовному концерті-реквіємі» [див. докладно: 1, с. 419-436], складні гармонічні комплекси 3 їх несподіваними розв'язаннями стають лейтзворотами упродовж великої циклічної композиції- «Літургії святого Іоанна Златоустого» [див. докладний аналіз усіх 18 частин літургії: 2, с. 571-579.]. При цьому оновлення музичної мови відбувається не заради оновлення, а як наслідок концепційної експресіонізації в духовних творах композитора, яким властивий надзвичайно високий емоційний «градус», драматизм i навіть трагедійність. Від самого початку, з перших же акордів і надалі, до самого кінця твору композитор тримає слухачів у напруженні, в очікуванні «результату»- висновку, відповіді, яку шукає для себе сучасна людина. Олександр Козаренко, аналізуючи інструментальні твори Мирослава Скорика, зазначив, що вони «репрезентують інтегральний тип його пізнього вислову, своєрідний романтизований експресіонізм» [3, с. 24]. Як видається, таке визначення можна застосувати i до духовних творів композитора.

Однією з нових ознак духовної творчості сучасних композиторів, зокрема і Мирослава Скорика, є ставлення до вербального тексту, більш вільне поводження 3 ним. Яскравий приклад - «Духовний концерт-реквієм», у якому поєднані різні тексти («Святий Боже», «Отче наш», «Алилуя», «Плачу і ридаю» та ін.). Складна багаточастинна композиція концерту вибудовується як процес співставлення різних станів, як безперервний пошук світла, заспокоєння, виправдання.

Трансформаційні процеси, що відбуваються в сучасній духовній творчості, торкаються різних жанрових ознак, наприклад, одного з базових, типологічних елементів духовного концерту - співвідношення хорового tutti та soli. Так, у «Духовному концерті» М. Скорика замість традиційних ансамблів солістів використовуються персоніфіковані соло сопрано і тенора, що має важливе концепційне значення (іноді ж у сучасному духовному концерті взагалі може бути майже відсутнє ансамблеве або сольне звучання, як у вже згаданому концерті I. Тилика). 
Отже, духовні твори Мирослава Скорика, які $\epsilon$ безцінною складовою української і світової музики, є по-справжньому сучасними, співзвучними духовним пошукам багатьох наших співгромадян, тож вони назавжди залишаться в історії музичного мистецтва не лише як сповідь геніальної людини, митця, а й як своєрідний правдивий документ нашої драматичної епохи, як правда про всіх нас і взагалі про людство.

\section{Література:}

1. Гусарчук Т. В. «Духовний концерт» Мирослава Скорика: концепційна трансгресія та іiі інтонаційне втілення. Науковий вісник Національної музичної академії Украӥни імені П. І. Чайковського : Вип. 86 : Історія в особистостях. Київ, 2013. С. 419-436.

2. Кияновська Л. О. Мирослав Скорик: людина і митець. Львів : Бібліотека журналу «Ї», 2008. 591 с.

3. Козаренко О. В. Творчість М. Скорика в контексті постмодернізму. Науковий вісник Національної музичної академії Украӥни імені П. І. Чайковського. Вип. 10 : Мирослав Скорик : збірник наукових праць, присвячений 60-річчю від дня народження М. М. Скорика. Київ : НМАУ ім. П. І. Чайковського, 2000. С. 23-30.

4. Скорик М. Духовні твори / заг. ред. та упоряд. М. Гобдича. Київ : Б-ка хору «Київ», 2005. 80 с.

5. Степурко В. І. Вияви мистецької інтроверсії у творчості композиторів України другої половини XX - початку XXI століття : автореф. дис. ... канд. мистецтвознавства (доктора філософії) : спец. 26.00.01 Теорія та історія культури / Нац. акад. керівних кадрів культури і мистецтв. Київ, 2017. 21 с. 